Article

\title{
The carboxylates formed on oxides promoting the aromatization in syngas conversion over composite catalysts
}

\author{
Zhiyang Chen a,b,c, Youming Ni a,b, Fuli Wen ${ }^{\mathrm{a}, \mathrm{b}, \mathrm{c}}$, Ziqiao Zhou a,b,c, Wenliang Zhu ${ }^{\mathrm{a}, \mathrm{b}, *}$, \\ Zhongmin Liu ${ }^{\mathrm{a}, \mathrm{b}, \mathrm{c}, \#}$ \\ a National Engineering Laboratory for Methanol to Olefins, Dalian Institute of Chemical Physics, Chinese Academy of Sciences, Dalian 116023, Liaoning, \\ China \\ b Dalian National Laboratory for Clean Energy, Dalian Institute of Chemical Physics, Chinese Academy of Sciences, Dalian 116023, Liaoning, China \\ c University of Chinese Academy of Sciences, Beijing 100049, China
}

\section{A R T I C L E I N F O}

\section{Article history:}

Received 2 June 2020

Accepted 19 June 2020

Available online 22 September 2020

\section{Keywords:}

Carboxylates

Syngas-to-aromatics

Composite catalysts

$\mathrm{ZnCrAlO}_{x}$

H-ZSM-5

\begin{abstract}
A B S T R A C T
Syngas to aromatics (STA) over bifunctional catalysts has attracted much attention in recent years, but the mechanism underlying the formation of aromatics remains controversial. The critical reaction intermediates, carboxylates, were first identified and then confirmed to essentially promote aromatization in the syngas conversion over a $\mathrm{ZnCrAlO}_{x} \& \mathrm{H}-\mathrm{ZSM}-5$ composite catalyst. This study provides evidence that the carboxylates can be formed during the reactions of formate species and olefins. In addition, it is shown that the carboxylates favor the formation of aromatics over H-ZSM-5 even in the presence of $\mathrm{H}_{2}$. A novel mechanism for the formation of aromatics via the generation and transformation of carboxylate intermediates is proposed, and the transformation of carboxylates to aromatics via methyl-2-cyclopenten-1-one (MCPO) intermediates is indeed likely. A better understanding of the formation mechanism of aromatics would help optimize the composite catalyst.
\end{abstract}

(C) 2021, Dalian Institute of Chemical Physics, Chinese Academy of Sciences. Published by Elsevier B.V. All rights reserved.

\section{Introduction}

Aromatics are important bulk chemicals that are primarily produced from petroleum via catalytic reforming or cracking [1]. However, there is increased market demand for the production of aromatics from non-petroleum resources such as coal, natural gas, or biomass. Syngas (a mixture of $\mathrm{CO}$ and $\mathrm{H}_{2}$ ) can be derived from these alternative resources, and it is commonly utilized as a platform for the synthesis of products such as gasoline [2,3] and olefins [4,5], which had originally been produced from petroleum. Fischer-Tropsch (F-T) synthesis is a well-established process for the transformation of syngas to hydrocarbons. However, the mechanism of carbon chain growth by $\mathrm{F}-\mathrm{T}$ synthesis renders the formation of aromatic hydrocarbons over the F-T catalysts difficult [6,7]. A composite catalyst produced by coupling F-T catalysts with H-ZSM-5 zeolites can produce aromatics through olefin oligomerization, hydrogen transfer, and dehydrogenation, but the selectivity of aromatics by this process is normally lower than $60 \%$ [8-10].

Recently, bifunctional catalysts comprising metal oxides and zeolites have shown excellent aromatic selectivity when utilized for syngas to aromatics (STA) [11-15]. Most mechanistic insights support the fact that methanol/DME formed on oxide catalysts could act as intermediates in reactions that yield aro-

\footnotetext{
* Corresponding author. Tel/Fax: +86-411-84379418; E-mail: wlzhu@dicp.ac.cn

\# Corresponding author. E-mail: liuzm@dicp.ac.cn

This work was supported by the National Natural Science Foundation of China (21978285), and the "Transformational Technologies for Clean Energy and Demonstration", the Strategic Priority Research Program of the Chinese Academy of Sciences (XDA21030100).

DOI: 10.1016/S1872-2067(20)63691-9 | http://www.sciencedirect.com/science/journal/18722067 | Chin. J. Catal., Vol. 42, No. 5, May 2021
} 
matics on zeolite catalysts. Nevertheless, some referenced experiments have revealed that methanol conversion reactions over zeolite catalysts in $\mathrm{CO}$ or $\mathrm{H}_{2}$ do not provide a yield of aromatics as high as that of STA over the corresponding composite catalyst $[11,12]$. This suggests that methanol/DME may not be the primary intermediate in the mechanistic route for STA reactions. Therefore, other mechanistic routes for producing aromatics over composite catalysts via STA are being considered. For example, Bao et al. reported that ketene was the intermediate in the formation of aromatics over $\mathrm{ZnCrO}_{x}-\mathrm{ZSM}-5$ [12]. More recently, Wei et al. found that the aldol-aromatic reaction mechanism played a key role in STA reactions $[16,17]$.

Herein, we report that the carboxylates formed by the reaction between formate species and olefins promote the aromatization in syngas conversion reactions over a $\mathrm{ZnCrA-}$ $10_{x} \&$ H-ZSM- 5 composite catalyst. A novel mechanistic route for the formation of aromatics via STA reactions is also proposed. Understanding the mechanism underlying the formation of aromatics would help optimize the composite catalyst.

\section{Experimental}

\subsection{Catalyst preparation}

The $\mathrm{ZnCrAlO}_{x}$ sample (Zn:Cr:Al = 1.10:1.13:1.16) was prepared by co-precipitation. Samples of $40.16 \mathrm{~g} \mathrm{Zn}\left(\mathrm{NO}_{3}\right)_{2} \cdot 6 \mathrm{H}_{2} \mathrm{O}$, $40.00 \mathrm{~g} \mathrm{Cr}\left(\mathrm{NO}_{3}\right)_{3} \cdot 9 \mathrm{H}_{2} \mathrm{O}$, and $37.50 \mathrm{~g} \mathrm{Al}\left(\mathrm{NO}_{3}\right)_{3} \cdot 9 \mathrm{H}_{2} \mathrm{O}$ were dissolved in $300 \mathrm{~mL}$ of distilled water. An aqueous solution containing 1.64 mol L-1 of $\left(\mathrm{NH}_{4}\right)_{2} \mathrm{CO}_{3}$ was used as the precipitant. The mixture was subjected to continuous stirring at $333 \mathrm{~K}$ at a constant $\mathrm{pH}$ of 7 for $1 \mathrm{~h}$ to allow precipitation, followed by aging for $3 \mathrm{~h}$ at the same temperature. The precipitant was then filtered and washed with distilled water, dried overnight at 373 $\mathrm{K}$, and calcinated at $773 \mathrm{~K}$ for $4 \mathrm{~h}$.

Nanosized Na-ZSM-5 zeolites were supplied by Zhongke New Catalytic Technology Company. The Na-ZSM-5 zeolites were transformed into $\mathrm{NH}_{4}-\mathrm{ZSM}-5$ by exchanging a $100 \mathrm{~g}$ sample of Na-ZSM-5 with $1 \mathrm{~L}$ of aqueous $\mathrm{NH}_{4} \mathrm{NO}_{3}\left(1 \mathrm{~mol} \mathrm{~L}^{-1}\right)$ at 353 $\mathrm{K}$ for $2 \mathrm{~h}$, followed by filtration and washing with deionized water. This process was repeated three times, and the samples were dried overnight at $373 \mathrm{~K}$. The samples were then calcinated at $823 \mathrm{~K}$ for another $4 \mathrm{~h}$ in air to obtain the desired H-ZSM- 5 zeolites. This preparation resulted in H-ZSM- 5 zeolites with a $\mathrm{SiO}_{2} / \mathrm{Al}_{2} \mathrm{O}_{3}$ ratio of 172 , as was determined by XRF analysis (PANalytical AXIOS).

The H-ZSM-5 samples with $\mathrm{SiO}_{2} / \mathrm{Al}_{2} \mathrm{O}_{3}$ ratios of 38 and 70 are the same as those in our recent studies [18].

\subsection{Catalytic tests}

Catalytic reactions were performed in a quartz-lined, continuous flow, fixed-bed stainless steel reactor. A $0.4 \mathrm{~g}$ sample of the composite catalyst (40-60 mesh) with a mass ratio of $\mathrm{ZnCrAlO}_{x} / \mathrm{H}-\mathrm{ZSM}-5=3: 1$ was packed in the reactor. The catalyst was first reduced in $\mathrm{H}_{2}$ atmosphere for $1 \mathrm{~h}$ at $573 \mathrm{~K}$. Then, the reaction was performed with a $\mathrm{H}_{2} / \mathrm{CO}$ mixture $\left(\mathrm{H}_{2} / \mathrm{CO}=1\right)$ at $4 \mathrm{MPa}, 633 \mathrm{~K}$, and $1500 \mathrm{~mL} \mathrm{~h}^{-1} \mathrm{gcat}^{-1}$. Ar was used as the in- ternal standard.

Methanol to aromatics (MTA) experiments were carried out in a quartz-lined, continuous flow, fixed-bed stainless-steel tubular reactor. A sample $(0.2 \mathrm{~g})$ of the H-ZSM-5 catalyst (40-60 mesh) was packed in the reactor. The catalyst was exposed to $\mathrm{N}_{2}$ for $4 \mathrm{~h}$ at $673 \mathrm{~K}$. The reaction was performed at $633 \mathrm{~K}$ and $4 \mathrm{MPa}$ with different feeds $\left(\mathrm{CO}+\mathrm{N}_{2}(1: 1), \mathrm{CO}+\mathrm{H}_{2}\right.$ (1:1), $\mathrm{N}_{2}+\mathrm{H}_{2}$ (1:1), and $\mathrm{N}_{2}$ ). Methanol was steadily fed into the reactor at a rate of $0.004 \mathrm{~mL} \mathrm{~min}^{-1}$ by a pump.

In the cofeeding experiment, liquid ethanol (EtOH) carried by a mixture of $\mathrm{CO}, \mathrm{H}_{2}$, and $\mathrm{C}_{3} \mathrm{H}_{6}$ was steadily fed into the reactor by a pump. The molar ratio of $\mathrm{CO} / \mathrm{H}_{2} / \mathrm{EtOH} / \mathrm{C}_{3} \mathrm{H}_{6}$ was 42.5:42.5:13.0:7.0, and the reaction was performed at $573 \mathrm{~K}$ and $0.1 \mathrm{MPa}$.

The conversion of propene and carboxylates over H-ZSM-5 in $\mathrm{N}_{2}$ or $\mathrm{H}_{2}$ was performed at $633 \mathrm{~K}$ and $1 \mathrm{MPa}$. $\mathrm{N}_{2}$ or $\mathrm{H}_{2}$ was bubbled through a stainless-steel saturator filled with methyl crotonate or methyl butyrate at $307 \mathrm{~K}$, and the ratio of $\mathrm{N}_{2}$ or $\mathrm{H}_{2} / \mathrm{C}_{3} \mathrm{H}_{6}$, methyl crotonate, or methyl butyrate was 81 (on a carbon basis).

All the reaction products were maintained in the gas phase and analyzed by online GC (Agilent 7890A) equipped with a Plot-Q capillary column connected to a flame ionization detector (FID) and a TDX-1 packed column connected to a thermal conductivity detector (TCD). The $\mathrm{CO}$ conversion and $\mathrm{CO}_{2}$ selectivity, as well as the selectivity for hydrocarbons $\left(\mathrm{C}_{n} \mathrm{H}_{m}\right), \mathrm{MeOH}$, and DME were calculated by applying the following equations:

$\mathrm{CO}$ conversion $=\left(\mathrm{CO}_{\text {in }}-\mathrm{CO}_{\text {out }}\right) / \mathrm{CO}_{\text {in }} \times 100 \%$

$\mathrm{CO}_{2}$ selectivity $=\mathrm{CO}_{2 \text {,out }} /\left(\mathrm{CO}_{\text {in }}-\mathrm{CO}_{\text {out }}\right) \times 100 \%$

COinlet: moles of $\mathrm{CO}$ at the inlet; $\mathrm{CO}_{\text {outlet: }}$ moles of $\mathrm{CO}$ at the outlet

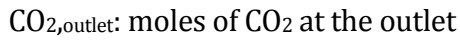

$\mathrm{C}_{n} \mathrm{H}_{m}$ selectivity $=N_{\mathrm{CnHm}} /$ (total carbon atoms of products detected by FID) $\times 100 \%$

$\mathrm{MeOH}$ selectivity $=N_{\mathrm{MeOH}} /$ (total carbon atoms in the products detected by FID) $\times 100 \%$

DME selectivity $=N_{\text {DME }} /$ (total carbon atoms in the products detected by FID) $\times 100 \%$

$N_{\mathrm{CnHm}}$ : carbon atom number of $\mathrm{C}_{n} \mathrm{H}_{m} ; N_{\mathrm{MeOH}}$ : carbon atom number of $\mathrm{MeOH}$

$N_{\text {DME: }}$ carbon atom number of DME

\subsection{Catalyst characterization}

In situ diffuse reflectance infrared Fourier transform spectroscopy (DRIFTS) was performed on a Bruker Tensor 27 instrument with an MCT detector. The samples were packed into a diffuse reflectance infrared cell with a $\mathrm{ZnSe}$ window. Prior to analysis, the sample was treated by a $\mathrm{H}_{2} / \mathrm{Ar}\left(\mathrm{H}_{2} / \mathrm{Ar}=3: 7\right)$ mixture at $573 \mathrm{~K}$ for $1 \mathrm{~h}$, and the background spectrum was collected under the same conditions. The samples were first treated in $\mathrm{CO}\left(5 \mathrm{~mL} \mathrm{~min}^{-1}\right)$ at $573 \mathrm{~K}$ for $30 \mathrm{~min}$, then purged in $\mathrm{N}_{2}$ at $20 \mathrm{~mL} \mathrm{~min}^{-1}$ and $573 \mathrm{~K}$ for $30 \mathrm{~min}$. After purging, $\mathrm{C}_{3} \mathrm{H}_{6}$ was introduced as $5 \% \mathrm{C}_{3} \mathrm{H}_{6}, 95 \% \mathrm{~N}_{2}$ at $5 \mathrm{~mL} \mathrm{~min}^{-1}$ and $573 \mathrm{~K}$ for $40 \mathrm{~min}$. The in situ DRIFT spectra were recorded by collecting 64 scans at $4 \mathrm{~cm}^{-1}$ resolution.

The FTIR spectrum after 2,6-di-tert-butyl-pyridine(DTBPy) 
adsorption was obtained on a Brucker Tensor 27 instrument with a resolution of $4 \mathrm{~cm}^{-1}$. The samples were pressed into a self-supporting wafer and evacuated in an IR cell at $673 \mathrm{~K}$ for 1 $\mathrm{h}$ before measurement and cooled to $423 \mathrm{~K}$, and the background spectrum was collected with 32 scans. Adsorption of DTBPy was conducted at $423 \mathrm{~K}$ for $10 \mathrm{~min}$ to ensure saturated loading, followed by evacuation at $423 \mathrm{~K}$ for $30 \mathrm{~min}$ before measurements.

In order to illustrate the evolution of $\mathrm{CO}$ and $\mathrm{H}_{2}$ to aromatics, the active species were analyzed by Guisnet's method [19]. The catalysts were quickly quenched by liquid nitrogen after the reaction proceeded for a predetermined amount of time, dissolved within $20 \% \mathrm{HF}$ solution, extracted by $\mathrm{CH}_{2} \mathrm{Cl}_{2}$, and finally analyzed by GC-MS (Agilent 7890/5975C).

\section{Results and discussion}

The results for syngas conversion over various composite catalysts were compared at $633 \mathrm{~K}$ and $4.0 \mathrm{MPa}$. The composite catalyst contained $\mathrm{ZnCrAlO}_{x}$ and $\mathrm{H}-\mathrm{ZSM}-5$. The XRD pattern of $\mathrm{ZnCrAlO}_{x}$ in Fig. S1 suggested a typical spinel structure, while that of H-ZSM-5 revealed an MFI structure. The acid property of H-ZSM- 5 was determined by $\mathrm{NH}_{3}$-TPD measurements (Fig. S2), and the density of acid sites was $0.109 \mathrm{mmol} \mathrm{g}^{-1}$, which indicated that the H-ZSM-5 we used is not strongly acidic. As presented in Fig. 1(a), the composite catalyst $\mathrm{ZnCrAlO}_{x} \& \mathrm{H}-\mathrm{ZSM}-5$, which was prepared by grinding the two components in an agate mortar, showed excellent aromatics selectivity of $72.9 \%$ with $32.1 \%$ CO conversion. However, if the two components were mixed in granule form $\left(\mathrm{ZnCrAlO}_{x}+\mathrm{H}-\mathrm{ZSM}-5\right)$, the selectivity of aromatics sharply decreased to $39.2 \%$. Upon further increasing the distance between the two components to complete separation, that is, the dual-bed mode $\left(\mathrm{ZnCrAlO}_{x} / \mathrm{H}-\mathrm{ZSM}-5\right)$, the selectivity for aromatics decreased to only $28.9 \%$. The above-mentioned three results demonstrated that increasing the proximity of the $\mathrm{ZnCrAlO}_{x}$ and $\mathrm{H}-\mathrm{ZSM}-5$ zeolite catalysts in a composite mixture can promote the formation of aromatics.

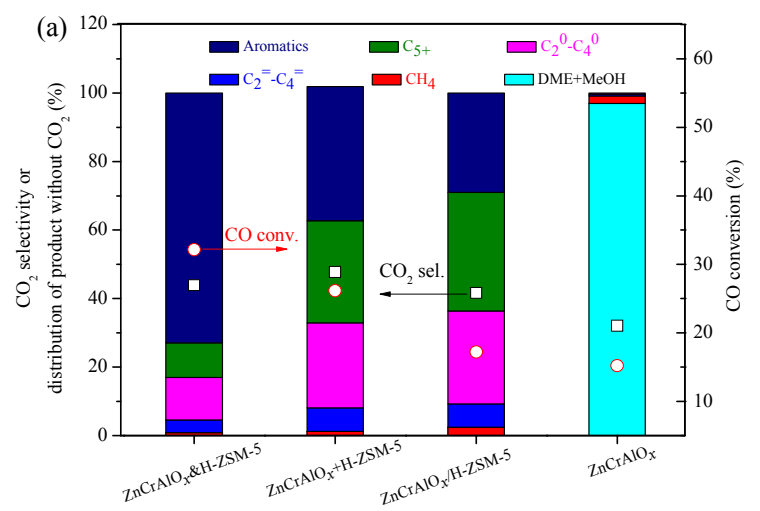

Similar phenomena have been commonly observed in previous works concerning STA reactions over composite catalysts [11-14]. The primary products obtained in the reactions over $\mathrm{ZnCrAlO}_{x}$ are $\mathrm{DME}$ and $\mathrm{MeOH}$, indicating that the aromatics are generated on H-ZSM-5 and not on $\mathrm{ZnCrAlO}_{x}$ for $\mathrm{ZnCrA-}$ $10_{x} \& H-Z S M-5$. Since oxides such as $\mathrm{ZnCrAlO}_{x}$ can convert syngas to $\mathrm{DME} / \mathrm{MeOH}$, and zeolites such as $\mathrm{H}-\mathrm{ZSM}-5$ can continuously transform them to aromatic hydrocarbons, it is generally believed that $\mathrm{DME} / \mathrm{MeOH}$ is an important intermediate for the formation of aromatics in STA reactions [11].

In order to confirm that $\mathrm{DME} / \mathrm{MeOH}$ may not be the primary intermediate during the formation of aromatics, the methanol conversion over H-ZSM-5 with cofeeding of various gases was studied (Fig. 1(b)). The formation rate of hydrocarbons and the partial pressures of $\mathrm{CO}$ and $\mathrm{H}_{2}$ are similar to those in the syngas conversion over $\mathrm{ZnCrAlO}_{x} \& \mathrm{H}-\mathrm{ZSM}-5$. It is clear that the selectivity for aromatics at different feeds over H-ZSM-5 follows this order: $\mathrm{MeOH}+\mathrm{CO}+\mathrm{N}_{2}>\mathrm{MeOH}+\mathrm{N}_{2}>\mathrm{MeOH}+\mathrm{CO}+\mathrm{H}_{2}>$ $\mathrm{MeOH}+\mathrm{N}_{2}+\mathrm{H}_{2}$. This suggests that $\mathrm{CO}$ can promote the aromatization, whereas $\mathrm{H}_{2}$ can suppress it. Previous studies have demonstrated that the acid sites of zeolites can simultaneously catalyze carbonylation [11,18] and hydrogenation [20-23]. The former is beneficial to the formation of aromatic hydrocarbons $[11,18]$, whereas the latter is just the opposite $[22,23]$. Considering these phenomena in methanol conversion, if the aromatics in the syngas conversion over $\mathrm{ZnCrAlO}_{x} \& \mathrm{H}-\mathrm{ZSM}-5$ are directly derived from the conversion of the methanol intermediate on H-ZSM-5 (Fig. 1(a)), their selectivity should be lower than those in the feed $\left(\mathrm{MeOH}+\mathrm{CO}+\mathrm{N}_{2}\right)$ conversion on $\mathrm{H}-\mathrm{ZSM}-5$ (Fig. 1(b)). However, this is not the case. The aromatics selectivity for methanol conversion in CO and $\mathrm{N}_{2}$ is only $42.0 \%$, which is much lower than that for the STA reaction $(72.9 \%)$. The catalytic performance for methanol conversion in $\mathrm{N}_{2}$ and CO over $\mathrm{ZnCrAlO}_{x} \& \mathrm{H}-\mathrm{ZSM}-5$ was also investigated. As shown in Fig. 1(b), the selectivity of aromatics (39.6\%) is also much lower than that for the STA reaction.

The effect of acid sites for H-ZSM-5 was investigated, and

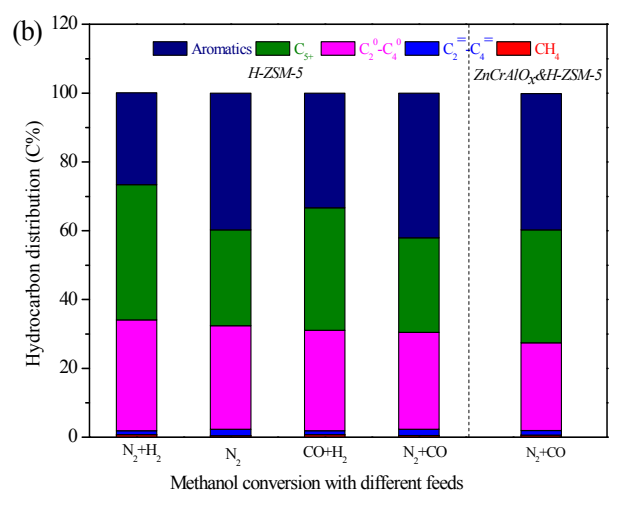

Fig. 1. Comparison of catalytic results for syngas and methanol conversion. (a) Syngas conversion over various composite catalysts. Space velocity = 2000 (only for $\mathrm{ZnCrAlO}_{x}$ ) or 1500 (for other catalysts) $\mathrm{mL} \mathrm{g}^{-1} \mathrm{~h}^{-1}, 4.0 \mathrm{MPa}, \mathrm{H}_{2} / \mathrm{CO} / \mathrm{Ar}=47.5: 47.5: 5$, $633 \mathrm{~K}$, time on stream = $3 \mathrm{~h}$. Note that $\mathrm{C}_{5+}$ excludes aromatics; $\mathrm{ZnCrAlO}_{x} \& \mathrm{H}-\mathrm{ZSM}-5$ prepared by grinding; $\mathrm{ZnCrAlO}_{x}+\mathrm{H}-\mathrm{ZSM}-5$ prepared by mixing granules; $\mathrm{ZnCrAlO}_{x} / \mathrm{H}-\mathrm{ZSM}-5$ denoted as dual-bed catalysts. (b) Methanol conversion over H-ZSM-5 and ZnCrAlO ${ }_{x} \& \mathrm{H}-\mathrm{ZSM}-5$ in various atmospheres. Space velocity = 6000 (for H-ZSM-5) and 1500 (for $\mathrm{ZnCrAlO}_{x} \& \mathrm{H}-\mathrm{ZSM}-5$ ) $\mathrm{mL} \mathrm{g}^{-1} \mathrm{~h}^{-1}$, liquid MeOH flow rate: $0.004 \mathrm{~mL} \mathrm{~min}^{-1}, 633 \mathrm{~K}, 4.0 \mathrm{Mpa}$, time on stream $=3 \mathrm{~h} . \mathrm{N}_{2}+\mathrm{H}_{2}$ denotes $\mathrm{N}_{2} / \mathrm{H}_{2} / \mathrm{MeOH}^{2} 4: 4: 1, \mathrm{~N}_{2}$ denotes $\mathrm{N}_{2} / \mathrm{MeOH}=8: 1, \mathrm{CO}+\mathrm{H}_{2}$ denotes $\mathrm{CO} / \mathrm{H}_{2} / \mathrm{MeOH}=4: 4: 1, \mathrm{~N}_{2}+\mathrm{CO}$ denotes $\mathrm{N}_{2} / \mathrm{CO} / \mathrm{MeOH}=4: 4: 1$. 

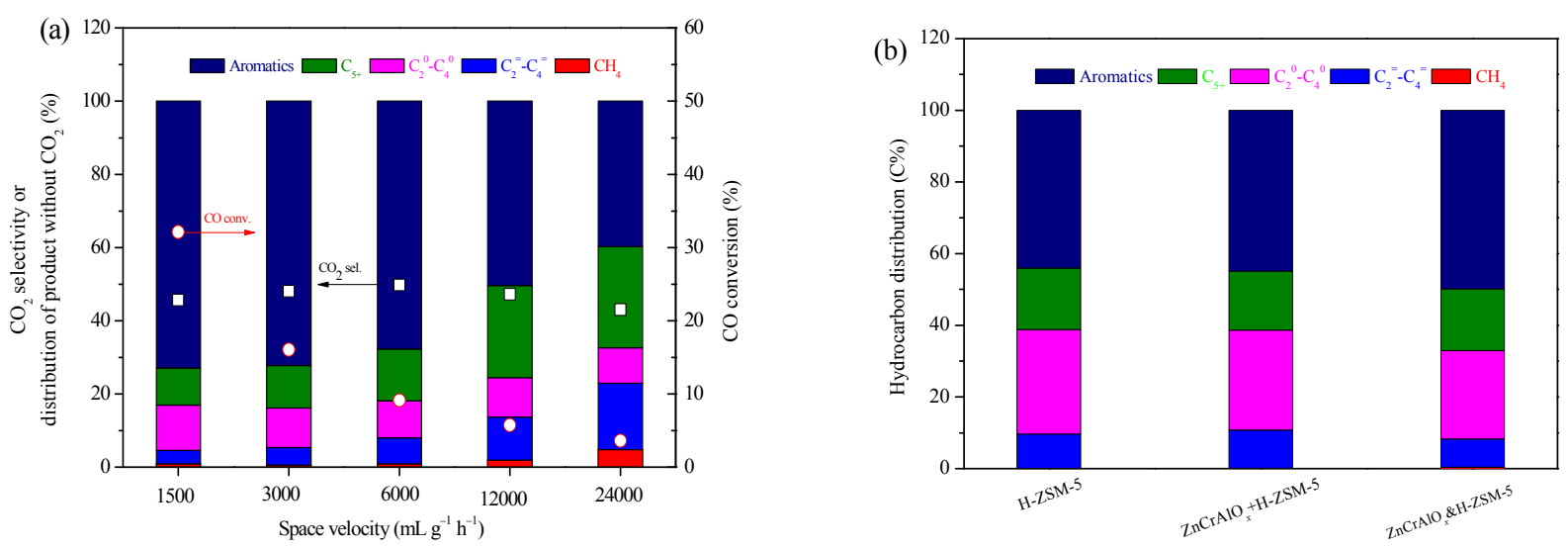

Fig. 2. Relationship between lower olefins and aromatics during the reactions. (a) Effect of space velocity on the formation of lower olefins and aromatics in syngas conversion over $\mathrm{ZnCrAlO}_{x} \& \mathrm{H}-\mathrm{ZSM}-5.4 .0 \mathrm{MPa}, \mathrm{H}_{2} / \mathrm{CO} / \mathrm{Ar}=47.5: 47.5: 5,633 \mathrm{~K}$, time on stream = 4 h. (b) Conversion of propene over various catalysts in CO. Reaction conditions: $633 \mathrm{~K}, 4 \mathrm{MPa}, \mathrm{CO}: \mathrm{He}_{3} \mathrm{C}_{3} \mathrm{H}_{6}=20: 19: 1$, space velocity $=6000$ (for $\mathrm{H}-\mathrm{ZSM}-5$ ) and 1500 (for other catalysts) $\mathrm{mL} \mathrm{h}^{-1} \mathrm{~g}^{-1}$, time on stream $=4 \mathrm{~h}$.

the result wa shown in Fig. S3. The aromatics selectivity decreases as the $\mathrm{SiO}_{2} / \mathrm{Al}_{2} \mathrm{O}_{3}$ ratio decreases (the number of acid sites increases), suggesting that H-ZSM-5 with a lower number of acid sites is beneficial for producing aromatics in STA. Meanwhile, previous studies have shown that in order to inhibit hydrogenation and improve the selectivity of aromatics, H-ZSM-5 zeolites with high $\mathrm{SiO}_{2} / \mathrm{Al}_{2} \mathrm{O}_{3}$ ratios must be selected for syngas conversion [11-14], but H-ZSM-5 zeolites with low $\mathrm{SiO}_{2} / \mathrm{Al}_{2} \mathrm{O}_{3}$ ratios are required for methanol to aromatics reactions [24-26]. This also suggests that methanol to aromatics reactions are not likely to be a major mechanistic route in STA reactions.

As shown in Fig. 2(a), for syngas conversion over ZnCrA$10_{x} \&$ H-ZSM-5, a decrease in the space velocity increases the formation of aromatics with the expense of $\mathrm{C}_{2}-\mathrm{C}_{4}$ olefins, which has been commonly observed in the previous STA studies on composite catalysts [11-14]. This phenomenon is often used to prove that olefins act as intermediates to produce aromatics through olefin oligomerization, hydrogen transfer, and dehydrogenation [11,27], while olefins are produced through the

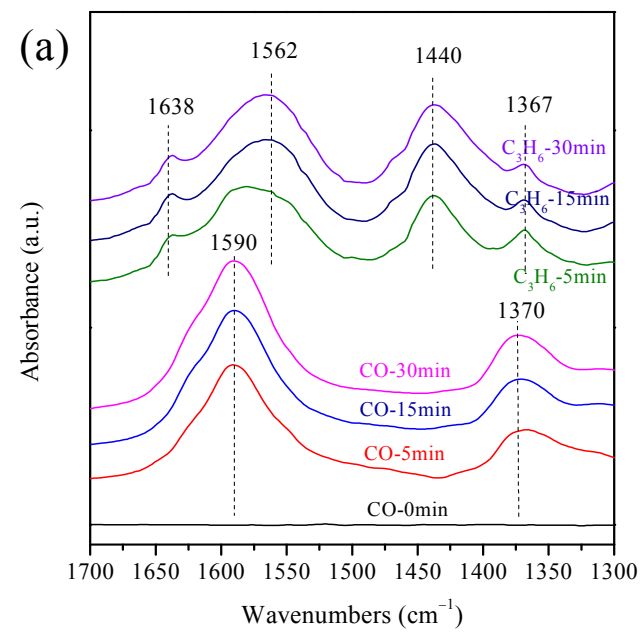

methanol to olefins (MT0) process [28-30]. If this view is correct, direct conversion of olefins, especially in a $\mathrm{CO}$ atmosphere, should result in aromatics selectivity no less than that for the corresponding syngas conversion, because it is reported that CO can promote the formation of aromatics $[11,18]$. However, it can be seen from Fig. 2(b) that propene conversion over H-ZSM-5, ZnCrAlO ${ }_{x} \& \mathrm{H}-\mathrm{ZSM}-5$, or $\mathrm{ZnCrAlO}_{x}+\mathrm{H}-\mathrm{ZSM}-5$ with CO cofeeding cannot result in aromatics selectivity as high as that for syngas conversion over $\mathrm{ZnCrAlO}_{x} \& \mathrm{H}-\mathrm{ZSM}-5$. The conversion of ethene over H-ZSM-5 and $\mathrm{ZnCrAlO}_{x} \& \mathrm{H}-\mathrm{ZSM}-5$ with CO cofeeding was also performed. As seen in Fig. S4, the aromatics selectivity with these catalysts is also much lower than that in the STA reactions. This suggests that the aromatics may not be directly generated from olefin oligomerization, hydrogen transfer, and dehydrogenation, which has been proven to be the aromatics formation route in MTA reactions [28-30]. Thus, we speculate that there is another species aside from methanol and olefins that forms aromatics via STA.

To gain further insight into the reaction mechanism of STA, DRIFTS experiments were performed. As shown in Figs. 3(a)

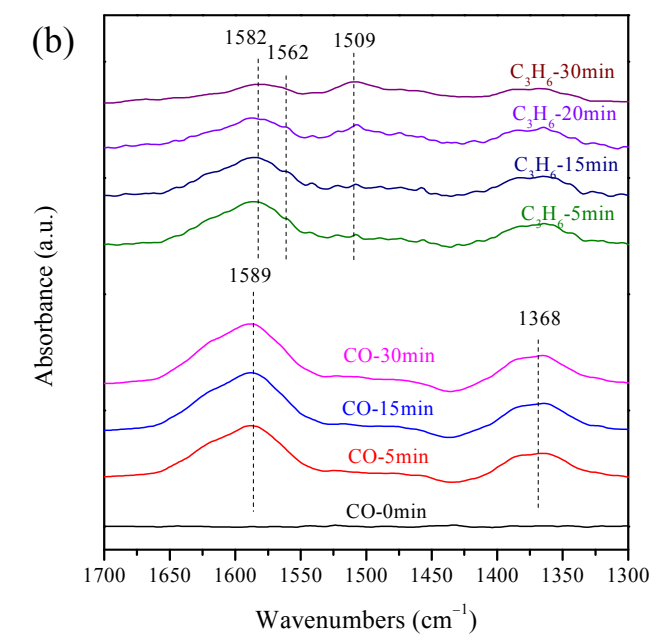

Fig. 3. In situ DRIFT spectra for the conversion of $\mathrm{CO}$ and $\mathrm{C}_{3} \mathrm{H}_{6}$ over $\mathrm{ZnCrAlO}_{x}(\mathrm{a})$ and $\mathrm{ZnCrAlO}_{x} \& \mathrm{H}-\mathrm{ZSM}-5$ (b). Reaction conditions: $0.1 \mathrm{MPa}, 573 \mathrm{~K}$, $\mathrm{CO}$ $=5 \mathrm{~mL} \mathrm{~min}^{-1}, \mathrm{C}_{3} \mathrm{H}_{6}\left(5 \% \mathrm{C}_{3} \mathrm{H}_{6}+95 \% \mathrm{~N}_{2}\right)=5 \mathrm{~mL} \mathrm{~min}^{-1}$. 
and S5(a), after $\mathrm{CO}$ was adsorbed on the pre-reduced $\mathrm{ZnCrAlO}_{x}$ surface at $573 \mathrm{~K}$, the formate species $(2958,2868,2744,1591$, and $1370 \mathrm{~cm}^{-1}$ ) were observed, and the peak intensity increased with an increase in the time for CO adsorption [31]. The formate species could be formed through the interaction of CO with surface hydroxyl groups on the $\mathrm{ZnCrAlO}_{x}$ surface $[32,33]$. When $\mathrm{C}_{3} \mathrm{H}_{6}$ was introduced into the cell after $\mathrm{N}_{2}$ flush, the COO stretching vibration at $1592 \mathrm{~cm}^{-1}$ began to shift to $1562 \mathrm{~cm}^{-1}$. Moreover, a band at $1638 \mathrm{~cm}^{-1}$ appeared and its intensity was enhanced upon increasing the $\mathrm{C}_{3} \mathrm{H}_{6}$ adsorption time. This suggests that some unknown species were formed after the introduction of $\mathrm{C}_{3} \mathrm{H}_{6}$. As shown in Figs. 3(b) and S5(b), the formate species $\left(2960,2873,2744,1589,1368 \mathrm{~cm}^{-1}\right)$ were also observed on the pre-reduced $\mathrm{ZnCrAlO}_{x} \& \mathrm{H}-\mathrm{ZSM}-5$ surface after the adsorption of $\mathrm{CO}$ at $573 \mathrm{~K}$. As $\mathrm{C}_{3} \mathrm{H}_{6}$ was introduced, the band at $1589 \mathrm{~cm}^{-1}$ shifted to a smaller wavenumber (1583 $\mathrm{cm}^{-1}$ ), and then, its intensity gradually decreased. Meanwhile, a band at $1562 \mathrm{~cm}^{-1}$ was observed, which could also be seen in the case of the reaction over $\mathrm{ZnCrAlO}_{x}$, indicating that the formate species might react with $\mathrm{C}_{3} \mathrm{H}_{6}$ to form some new species. The band at $1509 \mathrm{~cm}^{-1}$ was also observed after the introduction of $\mathrm{C}_{3} \mathrm{H}_{6}$, which was ascribed to aromatics $[34,35]$. These in situ DRIFTS results suggest that some unknown species are generated by the reaction of the formate species with propene on the $\mathrm{ZnCrAlO}_{x}$ surface and that they continuously transform to aromatics over H-ZSM-5.

To identify the unknown species observed in in situ DRIFTS, we attempted to desorb them from the surface of $\mathrm{ZnCrAlO}_{x}$. Considering that ethanol could react with some adsorbed organic groups to yield ethers and esters [36], a mixture of $\mathrm{CO}, \mathrm{H}_{2}$, $\mathrm{C}_{3} \mathrm{H}_{6}$ and ethanol was introduced into $\mathrm{ZnCrAlO}_{x}$ at $573 \mathrm{~K}$ and $0.1 \mathrm{MPa}$. Interestingly, carboxylates such as ethyl butyrate and ethyl crotonate were formed (Fig. 4(a)). Moreover, a characteristic band at $1566 \mathrm{~cm}^{-1}$, which was ascribed to the COO stretching vibration of the unsaturated carboxylates, could be observed in the DRIFTS profile of zinc methacrylate (Fig. 4(b)). This indicates that unsaturated carboxylate species (corresponding band at $1562 \mathrm{~cm}^{-1}$ ) can be formed on the surface of

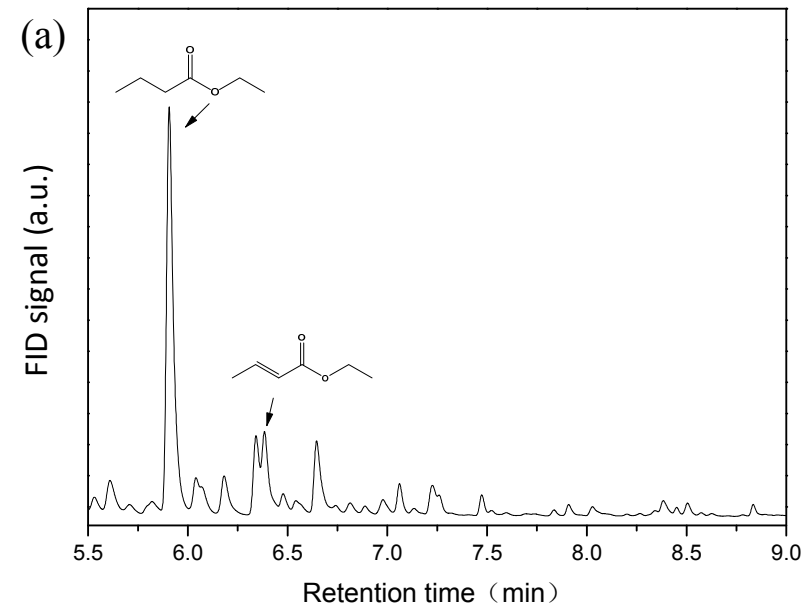

$\mathrm{ZnCrAlO}_{x}$ (Fig. 3(a)). The transformation of formate groups into unsaturated carboxylates, which led to the formation of conjugated carbonyl groups, causes this redshift of the peaks attributed to the formate groups [37]. The unsaturated carboxylates have been proposed to be formed via formate species inserted with alkyl species $\left(\mathrm{C}_{3} \mathrm{H}_{6}\right)$ on metal oxide catalysts $[36,38,39]$. The band at $1644 \mathrm{~cm}^{-1}$ for zinc methacrylate can be assigned to the $\mathrm{C}=\mathrm{C}$ stretching vibration $[34,35]$, further confirming the formation of unsaturated carboxylate species on $\mathrm{ZnCrAlO}_{x}$ (Fig. 3(a)). It is noted that the amount of saturated carboxylates is higher than that of unsaturated carboxylates in Fig. 4(a), and this difference might contribute to the hydrogenation of unsaturated carboxylates in the presence of $\mathrm{H}_{2}$.

To understand the effect of the carboxylates in STA reactions, $\mathrm{C}_{3} \mathrm{H}_{6}$ was co-fed with methyl crotonate over H-ZSM-5 at $633 \mathrm{~K}$ and $0.1 \mathrm{MPa}$ in $\mathrm{N}_{2}$ atmosphere. As shown in Fig. 5(a), increasing the methyl crotonate concentration can obviously enhance the formation of aromatics, suggesting that carboxylates can promote the aromatization. It has been reported that the Brønsted acid sites of zeolite scan catalyze hydrogenation [20-23], which is detrimental to the aromatization. As shown in Fig. 5(b), the presence of $\mathrm{H}_{2}$ during the propene conversion over H-ZSM-5 results in a dramatic decrease in the formation of aromatics, which also supports the above mentioned view. Notably, carboxylate conversion yields a higher amount of aromatics than does propene conversion; at the same time, the suppression of aromatization in the former case is less sensitive than that in the latter. Therefore, it can be inferred that carboxylates play a key role in the formation of aromatics in STA reactions.

ZnCrAlO $\&$ H-ZSM-5 and H-ZSM-5 were characterized based on their FTIR spectra after 2,6-di-tert-butyl-pyridine absorption (DTBPy-FTIR). As shown in Fig. 6(a), the bands at 3365, 1614 , and $1531 \mathrm{~cm}^{-1}$ are attributed to DTBPy adsorbed on the Brønsted acid sites on the external surface of H-ZSM-5 [40,41]. The negative band at $3742 \mathrm{~cm}^{-1}$ is ascribed to the decrease in the number of bridging hydroxyls on the external surface. Compared with the case of H-ZSM-5, the intensity of the band at

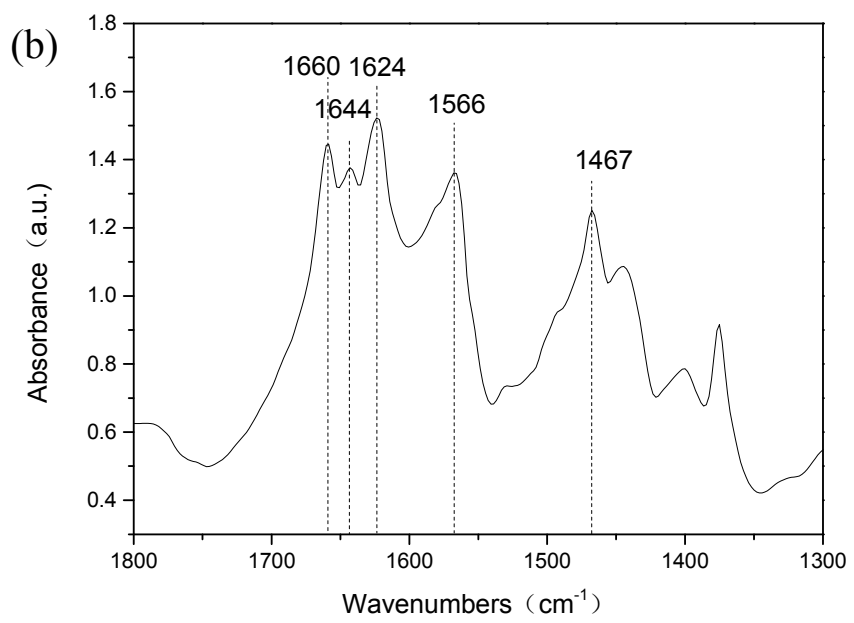

Fig. 4. Identification of carboxylates. (a) GC-MS profiles of products for the conversion of the mixture of $\mathrm{CO}, \mathrm{H}_{2}$, ethanol and $\mathrm{C}_{3} \mathrm{H}_{6}$ over $\mathrm{ZnCrAlO}_{x}$. Catalyst mass $=0.3 \mathrm{~g}$, space velocity $=2000 \mathrm{~mL} \mathrm{~min}^{-1}, \mathrm{CO} / \mathrm{H}_{2} / \mathrm{EtOH} / \mathrm{C}_{3} \mathrm{H}_{6}$ (molar ratio) $=42.5: 42.5: 13.0: 7.0,0.1 \mathrm{MPa}, 573 \mathrm{~K}$. (b) DRIFT spectra of zinc methacrylate as stand reference. 

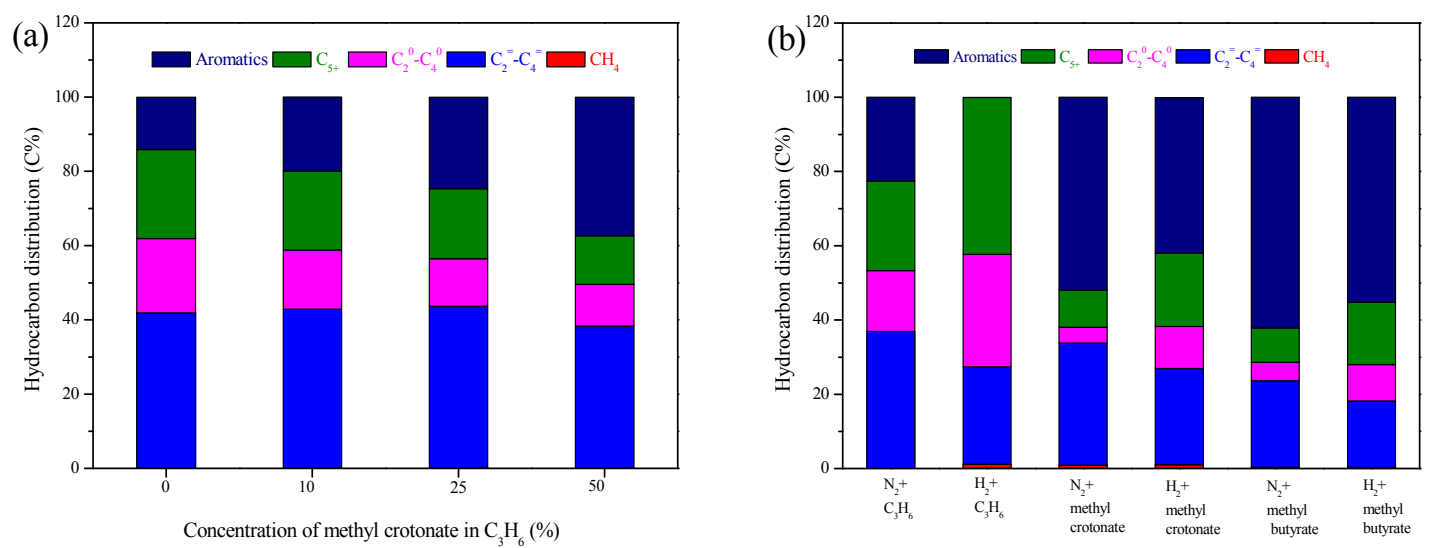

Fig. 5. Investigation of the role of carboxylates in the formation of aromatics via the STA reaction. (a) Effect of co-feeding methyl crotonate with $\mathrm{C}_{3} \mathrm{H}_{6}$ over H-ZSM-5 in $\mathrm{N}_{2}$ atmosphere. $633 \mathrm{~K}, 0.1 \mathrm{Mpa}$, space velocity $=1500 \mathrm{ml} \mathrm{h}^{-1} \mathrm{gcat}^{-1}$, time on stream $=2 \mathrm{~h}$. (b) Comparisons of propene and carboxylates conversions over H-ZSM-5 in $\mathrm{N}_{2}$ or $\mathrm{H}_{2} .1 .0 \mathrm{MPa}, 633 \mathrm{~K}$, ratio of $\mathrm{N}_{2}$ or $\mathrm{H}_{2} / \mathrm{C}_{3} \mathrm{H}_{6}$ to methyl crotonate or methyl butyrate = 81 (on a carbon basis), time on stream $=2 \mathrm{~h}$.

$3742 \mathrm{~cm}^{-1}$ is much lower for $\mathrm{ZnCrAlO}_{x} \& \mathrm{H}-\mathrm{ZSM}-5$, indicating that the external Brønsted acid sites of H-ZSM-5 are shielded by $\mathrm{ZnCrAlO}_{x}$, which is consistent with our recent report [40]. This shielding may suppress olefin hydrogenation and finally promote the aromatization in the STA reaction.

The effect of the proximity of the two catalysts in the composite catalyst was investigated by testing them under the same conditions as described in Fig. 1(a), followed by quenching with liquid nitrogen; then, the active species were extracted and analyzed by GC-MS following Guisnet's method [19]. As shown in Fig. 6(b), the primary organics retained in the catalysts after syngas conversion were polymethylbenzenes and methyl-2-cyclopenten-1-ones (MCPOs). The amount of MCPO selectivity in the catalysts follows this order: $\mathrm{ZnCrA}$ $1 \mathrm{IO}_{x} / \mathrm{H}-\mathrm{ZSM}-5<\mathrm{ZnCrAlO}_{x}+\mathrm{H}-\mathrm{ZSM}-5<\mathrm{ZnCrAlO}_{x} \& \mathrm{H}-\mathrm{ZSM}-5$, which is the same order for aromatic selectivity. It indicates that MCPOs are important intermediates to form aromatics. This phenomenon has actually been observed in recent works
$[18,42]$. It can be noted in Fig. 6(b) and Table S1 that a few carboxylate species such as 2-methyl-propanoic acid can be observed in the $\mathrm{ZnCrAlO}_{x} \& \mathrm{H}-\mathrm{ZSM}-5$ composite catalyst, while the amount of carboxylate species in these catalysts in Fig. 4 also follows the order: $\mathrm{ZnCrAlO}_{x} / \mathrm{H}-\mathrm{ZSM}-5<\mathrm{ZnCrAlO}_{x}+\mathrm{H}-\mathrm{ZSM}-5$ $<\mathrm{ZnCrAlO}_{x} \& \mathrm{H}-\mathrm{ZSM}-5$. As discussed in the results of Fig. S7, closer proximity of the two components could weaken the hydrogenation of olefins which would promote the formation of these carboxylate species. Besides, it has been demonstrated that MCPOs could be produced from carboxylate species $[18,43,44]$.

Accounting for all of the above results, we are proposing a mechanism for the formation of aromatics in STA reactions over a $\mathrm{ZnCrAlO}_{x} \& \mathrm{H}-\mathrm{ZSM}-5$ composite catalyst (Scheme 1). At the beginning, formate species are generated by the reaction of $\mathrm{CO}$ and $\mathrm{H}_{2}$ on the surface of $\mathrm{ZnCrAlO}_{x}$, which is proven by the in situ FTIR results obtained in this study and others. Then, some of the formate species undergo further hydrogenation to
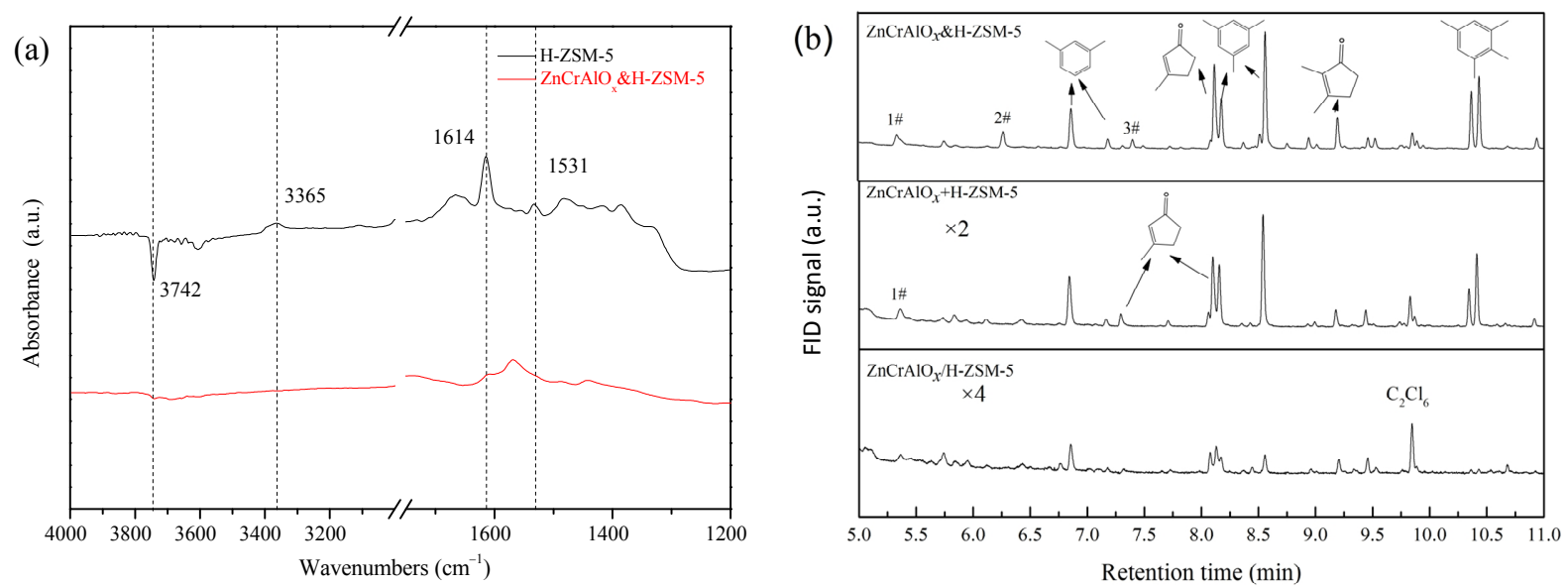

Fig. 6. The effect of the proximity of oxide and zeolite on the acidic property of H-ZSM-5 and the formation of retained organics. (a) FTIR subtraction relative to adsorption of DTBPy. (b) GC-MS chromatograms of retained organics in various catalysts after syngas conversion. Space velocity $=1500$ $\mathrm{mL} \mathrm{g}^{-1} \mathrm{~h}^{-1}, 4.0 \mathrm{MPa}, \mathrm{H}_{2} / \mathrm{CO} / \mathrm{Ar}=47.5 / 47.5 / 5,633 \mathrm{~K}$, time on stream = 1 min. Peak numbers correspond to compounds listed in Table S1. 


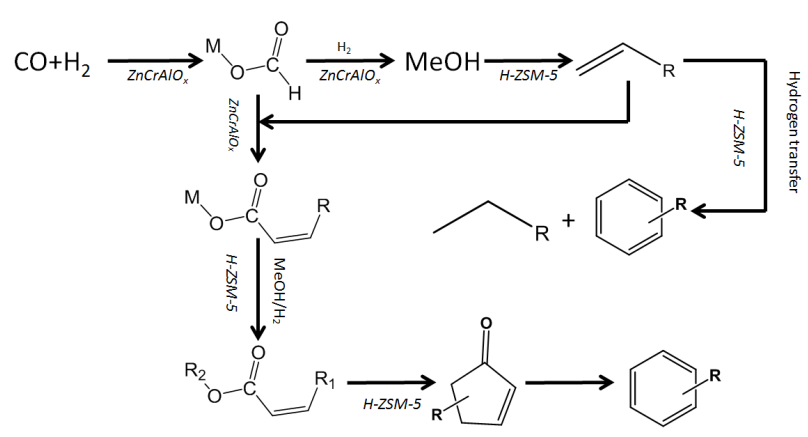

Scheme 1. Proposed mechanism of the STA reaction over a composite catalyst. $\mathrm{M}$ denotes $\mathrm{ZnCrAlO}_{x} ; \mathrm{R}, \mathrm{R}_{1}$, and $\mathrm{R}_{2}$ denote $\mathrm{H}$ and alkyl groups.

methanol or DME, which are desorbed from $\mathrm{ZnCrAlO}_{x}$ and transferred to H-ZSM-5. After that, olefins can be produced via the MTO reaction. A portion of olefins can react with some of the formate species to form carboxylate species on $\mathrm{ZnCrAlO}_{x}$, which is supported by the results shown in Figs. 3(a) and 4. These surface carboxylate species can be transformed to carboxylates in the presence of $\mathrm{H}_{2}$ or methanol over $\mathrm{ZnCrAlO}_{x}$ and then transferred to H-ZSM-5, which is supported by the results shown in Fig. 6(b) and Table S1. Finally, carboxylates are converted to aromatics, presumably via MCPO intermediates. Reasonable proximity of the two catalyst components can decrease the acidity at the external Brønsted sites of H-ZSM-5 thereby weakening hydrogenation, which helps promote the aromatization.

\section{Conclusions}

In summary, carboxylates were first identified as critical intermediates and then confirmed to essentially promote aroma- tization in the conversion of syngas over a $\mathrm{ZnCrAlO}_{x} \& \mathrm{H}-\mathrm{ZSM}-5$ composite catalyst. A novel mechanism for the formation of aromatics via the formation and transformation of carboxylate intermediates is proposed. These carboxylates have been shown to form in the reaction of formate species and olefins over $\mathrm{ZnCrAlO}_{x}$. After being transferred to H-ZSM-5, the carboxylate species are finally converted to aromatics, probably via MCPO intermediates. A better understanding of the formation mechanism of aromatics would help to optimize the composite catalyst.

\section{Competing interests}

The authors declare no competing financial interests.

\section{Acknowledgments}

We thank Yanli He and Yijun Zheng for assistance in the experiments.

\section{References}

[1] A. M. Niziolek, O. Onel, C. A. Floudas, ALChE J., 2016, 62, 1531-1556.

[2] N. Duyckaerts, M. Bartsch, I. T. Trotus, N. Pfander, A. Lorke, F. Schuth, G. Prieto, Angew. Chem. Int. Ed., 2017, 56, 11480-11484.

[3] N. Li, F. Jiao, X. Pan, Y. Chen, J. Feng, G. Li, X. Bao, Angew. Chem. Int. Ed., 2019, 58, 7400-7404.

[4] F. Jiao, J. Li, X. Pan, J. Xiao, H. Li, H. Ma, M. Wei, Y. Pan, Z. Zhou, M. Li, S. Miao, J. Li, Y. Zhu, D. Xiao, T. He, J. Yang, F. Qi, Q. Fu, X. Bao, Science, 2016, 351, 1065-1068.

[5] K. Cheng, B. Gu, X. Liu, J. Kang, Q. Zhang, Y. Wang, Angew. Chem. Int. Ed., 2016, 55, 4725-4728.

[6] C. D. Chang, W. H. Lang, A. J. Silvestri, J. Catal., 1979, 56, 268-273.

[7] S. Sartipi, M. Makkee, F. Kapteijn, J. Gascon, Catal. Sci. Technol.,

\section{Graphical Abstract}

Chin. J. Catal., 2021, 42: 835-843 doi: 10.1016/S1872-2067(20)63691-9

The carboxylates formed on oxides promoting the aromatization in syngas conversion over composite catalysts

Zhiyang Chen, Youming Ni, Fuli Wen, Ziqiao Zhou, Wenliang Zhu *, Zhongmin Liu*

Dalian Institute of Chemical Physics, Chinese Academy of Sciences;

University of Chinese Academy of Sciences

A novel mechanistic route for the formation of aromatics in STA reactions is proposed. The critical intermediates, carboxylates, are proven to be formed by the reaction between formate species and olefins over $\mathrm{ZnCrAlO}_{x}$. Carboxylates are also shown to essentially promote aromatization in the conversion of syngas over a $\mathrm{ZnCrA}$ $1 \mathrm{O}_{x} \& \mathrm{H}-\mathrm{ZSM}-5$ composite catalyst.

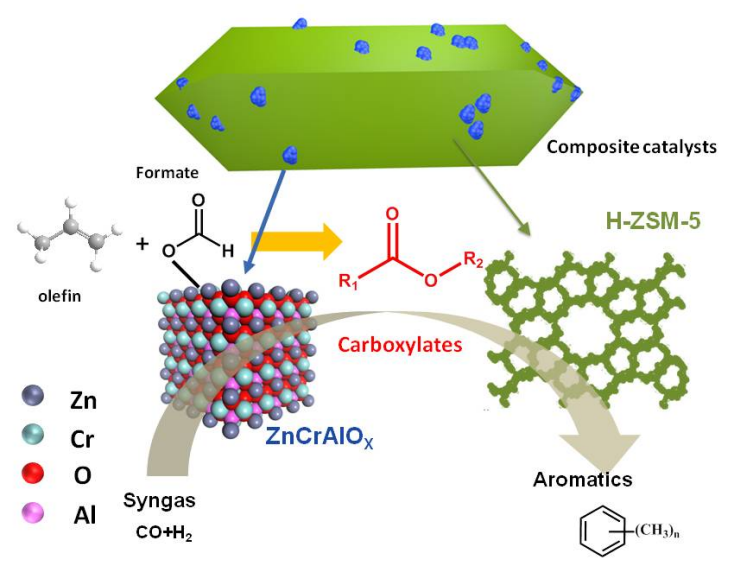


2014, 4, 893-907.

[8] B. Zhao, P. Zhai, P. Wang, J. Li, T. Li, M. Peng, M. Zhao, G. Hu, Y. Yang, Y.-W. Li, Q. Zhang, W. Fan, D. Ma, Chem, 2017, 3, 323-333.

[9] Y. Xu, D. Liu, X. Liu, Appl. Catal. A, 2018, 552, 168-183.

[10] Y. Xu, J. Liu, J. Wang, G. Ma, J. Lin, Y. Yang, Y. Li, C. Zhang, M. Ding, ACS Catal., 2019, 9, 5147-5156.

[11] K. Cheng, W. Zhou, J. Kang, S. He, S. Shi, Q. Zhang, Y. Pan, W. Wen, Y. Wang, Chem, 2017, 3, 334-347.

[12] J. Yang, X. Pan, F. Jiao, J. Li, X. Bao, Chem. Commun., 2017, 53, 11146-11149.

[13] Z. Huang, S. Wang, F. Qin, L. Huang, Y. Yue, W. Hua, M. Qiao, H. He, W. Shen, H. Xu, ChemCatChem, 2018, 10, 4519-4524.

[14] W. Zhou, S. Shi, Y. Wang, L. Zhang, Y. Wang, G. Zhang, X. Min, K. Cheng, Q. Zhang, J. Kang, Y. Wang, ChemCatChem, 2019, 11, 1681-1688.

[15] Y. Fu, Y. Ni, W. Zhu, Z. Liu, J. Catal., 2020, 383, 97-102.

[16] M. T. Arslan, B. A. Qureshi, S. Z. A. Gilani, D. Cai, Y. Ma, M. Usman, X. Chen, Y. Wang, F. Wei, ACS Catal., 2019, 9, 2203-2212.

[17] M. T. Arslan, B. Ali, S. Z. A. Gilani, Y. Hou, Q. Wang, D. Cai, Y. Wang, F. Wei, ACS Catal, 2020, 10, 2477-2488.

[18] Z. Chen, Y. Ni, Y. Zhi, F. Wen, Z. Zhou, Y. Wei, W. Zhu, Z. Liu, Angew. Chem. Int. Ed., 2018, 57, 12549-12553.

[19] M. Guisnet, P. Magnoux, Appl. Catal., 1989, 54, 1-27.

[20] J. Kanai, J. A. Martens, P. A. Jacobs, J. Catal., 1992, 133, 527-543.

[21] R. Gounder, E. Iglesia, J. Catal, 2011, 277, 36-45.

[22] S. S. Arora, D. L. S. Nieskens, A. Malek, A. Bhan, Nat. Catal., 2018, 1, 666-672.

[23] X. Zhao, J. Li, P. Tian, L. Wang, X. Li, S. Lin, X. Guo, Z. Liu, ACS Catal., 2019, 9, 3017-3025.

[24] Y. Song, X. Zhu, S. Xie, Q. Wang, L. Xu, Catal. Lett., 2004, 97, 31-36.

[25] Y. Ni, A. Sun, X. Wu, J. Hu, T. Li, G. Li, Chin. J. Chem. Eng., 2011, 19, 439-445.

[26] V. R. Choudhary, V. S. Nayak, Zeolites, 1985, 5, 325-328.
[27] Z. Li, Y. Qu, J. Wang, H. Liu, M. Li, S. Miao, C. Li, Joule, 2019, 3, 570-583.

[28] X. Sun, S. Mueller, H. Shi, G. L. Haller, M. Sanchez-Sanchez, A. C. van Veen, J. A. Lercher, J. Catal., 2014, 314, 21-31.

[29] S. Ilias, A. Bhan, ACS Catal., 2012, 3, 18-31.

[30] X. Sun, S. Mueller, Y. Liu, H. Shi, G. L. Haller, M. Sanchez-Sanchez, A. C. van Veen, J. A. Lercher, J. Catal., 2014, 317, 185-197.

[31] S. Fujita, M. Usui, H. Ito, N. Takezawa, J. Catal., 1995, 157, 403-413.

[32] X. Liu, W. Zhou, Y. Yang, K. Cheng, J. Kang, L. Zhang, G. Zhang, X. Min, Q. Zhang, Y. Wang, Chem. Sci., 2018, 9, 4708-4718.

[33] N. B. Jackson, J. G. Ekerdt, J. Catal., 1986, 101, 90-102.

[34] L. Palumbo, F. Bonino, P. Beato, M. Bjørgen, A. Zecchina, S. Bordiga, J. Phys. Chem. C, 2008, 112, 9710-9716.

[35] M. Rozwadowski, M. Lezanska, J. Wloch, K. Erdmann, R. Golembiewski, J. Kornatowski, Chem. Mater., 2001, 13, 1609-1616.

[36] Y. Yang, L. Wang, K. Xiao, T. Zhao, H. Wang, L. Zhong, Y. Sun, Catal. Sci. Technol., 2015, 5, 4224-4232.

[37] Y. Liu, F. M. Kirchberger, S. Muller, M. Eder, M. Tonigold, M. Sanchez-Sanchez, J. A. Lercher, Nat. Commun., 2019, 10, 1462.

[38] T. Lin, X. Qi, X. Wang, L. Xia, C. Wang, F. Yu, H. Wang, S. Li, L. Zhong, Y. Sun, Angew. Chem. Int. Ed., 2019, 58, 4627-4631.

[39] H. T. Luk, C. Mondelli, D. C. Ferre, J. A. Stewart, J. Perez-Ramirez, Chem. Soc. Rev., 2017, 46, 1358-1426.

[40] Y. Ni, Z. Chen, Y. Fu, Y. Liu, W. Zhu, Z. Liu, Nat. Commun., 2018, 9, 3457.

[41] A. Ungureanu, T. V. Hoang, D. Trong On, E. Dumitriu, S. Kaliaguine, Appl. Catal. A, 2005, 294, 92-105.

[42] Z. Liu, X. Dong, X. Liu, Y. Han, Catal. Sci. Technol., 2016, 6, 8157-8165.

[43] L. Yang, T. Yan, C. Wang, W. Dai, G. Wu, M. Hunger, W. Fan, Z. Xie, N. Guan, L. Li, ACS Catal., 2019, 9, 6491-6501.

[44] Y. Ni, W. Zhu, Z. Liu, ACS Catal., 2019, 9, 11398-11403.

\title{
金属氧化物催化剂上合成气转化中羧酸盐物种促进芳烃的生成
}

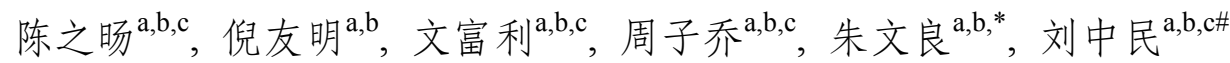 \\ a中国科学院大连化学物理研究所, 甲醇制烯烃国家工程实验室, 辽宁大连 116023

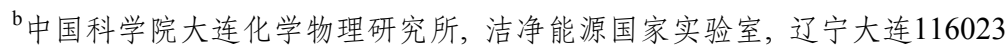 \\ ${ }^{\mathrm{c}}$ 中国科学院大学, 北京 100049
}

摘要: 芳烃是重要的化工原料, 目前主要通过石油催化裂化和催化重整制得. 随着石油资源的消耗以及芳烃的需求日益增 长, 开发非石油路线制备芳烃势在必行. 因此, 从煤、天然气和生物质出发, 经合成气一步制芳烃(STA)广受关注. 将合成气 制甲醇的金属催化剂和甲醇制芳烃的分子篮催化剂复合, 可以制备双功能催化剂, 用于合成气反应可高选择性得到芳烃. 然而, 关于此过程中芳烃的生成机理仍有争论. 目前人们认为, 生成芳烃的中间体主要分甲醇和其他含氧物种(乙烯酮, 醛 类)两种. 本文以 $\mathrm{ZnCrAlO}_{x}$ 和H-ZSM-5 为模型催化剂, 进行合成气制芳烃、甲醇制芳烃和丙烯制芳烃反应, 确定了传统的甲 醇制芳烃路径不是合成气制芳烃中的主要途径, 并通过原位傅里叶变换红外光谱和气相色质谱解释了STA反应中两种活 性组分距离越近, 芳烃选择性越高的原因, 从而提出了在合成气制芳烃过程中芳烃的生成机理.

通过比较双功能催化剂上合成气、甲醇以及丙烯的反应性能发现, 在甲醇和丙烯转化时, 其芳烃选择性远小于合成气 转化时的, 由此可认为, 在合成气制芳烃的路径主要不经由传统的甲醇制芳烃, 而是通过烯烃聚合脱氢生成芳烃.

红外表征和共进料实验表明, 合成气可以在金属催化剂表面生成甲酸盐物种, 它可与烯烃反应生成羧酸盐物种, 再迁 移到分子笁上反应生成芳烃, 且羧酸盐物种在分子篮上的芳构化能力要高于丙烯; 即使在氢气氛围下, 当丙烯的芳构化能 力受到氢气极大抑制时, 羧酸盐物种仍能高选择性生成芳烃.

本文制备了一系列金属催化剂和分子笁物理接近距离不同的双功能催化剂, 研究了合成气在双功能催化剂上制芳烃 时, 金属催化剂和分子篮二者组分的距离对芳烃选择性的影响. 随着二者接近距离的增加, 芳烃选择性急剧增加; 通过 GC-MS分析合成气转化时的停留物种, 发现随着二者接近距离的增加,羧酸盐物种和甲基环戊烯酮的量明显增加, 因此, 羧 
酸盐物种和甲基环戊烯酮物种在生成芳烃中起到了重要的作用.

综上所述, 我们提出了STA中一条新的芳烃生成路径, 并证明了羧酸盐物种是其中重要的中间物种. 它经由金属表面 的甲酸盐物种和烯烃反应生成, 随后迁移到分子篮上生成甲基环伐烯酮物种, 再脱水生成芳烃.

关键词: 羧酸盐; 合成气制芳烃; 复合催化剂; $\mathrm{ZnCrAlO}_{x} ; \mathrm{H}-\mathrm{ZSM}-5$

收稿日期: 2020-06-02. 接受日期: 2020-06-19. 出版日期: 上网日期: 2020-09-22.

*通讯联系人. 电话/传真: (0411)84379418; 电子信箱: wlzhu@dicp.ac.cn

”通讯联系人.电子信箱: liuzm@dicp.ac.cn

基金来源：国家自然科学基金(21978285); 中国科学院A类战略性先导科技专项课题(XDA21030100).

本文的电子版全文由Elsevier出版社在ScienceDirect上出版(http://www.sciencedirect.com/science/journal/18722067). 